\title{
PALEOSTRESS FIELDS AND 3-D STRUCTURE OF POLIPHASE SHEAR ZONES IN THE TRANSITION CRATON-OROGENIC BELT: EXAMPLES FROM THE NEOPROTEROZOIC OF SOUTHEASTERN BAHIA, BRAZIL
}

\section{LUIZ CÉSAR CORRÊA-GOMES ${ }^{1}$, CARLOS ROBERTO SOUZA FILHO ${ }^{2}$, ELSON PAIVA OLIVEIRA ${ }^{2}$}

\begin{abstract}
The IICSZ is a N45 -trending, 30km wide, intracratonic shear zone, extending for some $150 \mathrm{~km}$ through the SSE portion of the Bahia State. The IICSZ is closely related to dykes and syenites of the Alkaline Igneous Suite of Southern Bahia and, to the Southwest, it is interrupted by the $\mathrm{N} 140^{\circ}$-trending, Potiraguá Shear Zone (PSZ), that establishes the tectonic limit of the Neoproterozoic Araçuaí Fold Belt and the Archaean-Proterozoic São Francisco Craton. The PSZ dips to SW and the IICSZ to NW, though the latter swaps northeastwards into a symmetric, positive, flower structure.

A paleostress analysis based on the orientation of thousands of fault planes and fractures found in dykes and host rocks, coupled with the analysis of several kinematic indicators suggest that both shear zones evolved during a N-S compression and were later, perhaps progressively, reactivated by a E-W compressional tectonic event. Paleostress fields in both the IICSZ and PSZ were controlled by the orientation of the far-field stress, disturbances in field stress around re-activated shear zones, 3D-geometry of shear zones, tension concentration ('channeling') along shear zones, position of secondary faults and fractures, and orientation of shear zones, in relation to both the limit of the Aracuaí Fold Belt and the São Francisco Craton, and the site of intersection between the IICSZ and the PSZ (where the tension vectors converged to).
\end{abstract}

Keywords:

INTRODUCTION Shear zones are a common tectonic feature found in the transition between orogenic belts and cratons. They can be parallel, oblique or orthogonal to the orogen and have a complex geologic evolution, commonly including the intrusion of igneous rocks, tectonic reactivation and metamorphism. To study the structural evolution of such shear zones one must take into consideration the kinematic indicators associated with faults and fractures; observe the relative chronology between igneous intrusions and deformation; decipher the 3D geometry of the shear zones; and deduce the orientation of the stress fields that controlled their development.

In southeastern Bahia state, eastern Brazil, two regional-scale shear zones, i.e. the Potiraguá (PSZ) and the Itabuna-Itajú do Colônia Shear Zones (IICSZ), were mapped in the transition between the ArchaeanProterozoic São Francisco Craton and the Neoproterozoic Araçuai Fold Belt (Fig. 1). The N140 ${ }^{\circ}$-trending PSZ marks the limit between the Araçuai Fold Belt and the Craton, whereas the $\mathrm{N} 45^{\circ}$-trending IICSZ is a typical intracratonic shear zone. Both shear zones host alkaline dykes and batholiths of the Alkaline Igneous Suite of Southern Bahia.

This paper presents new field relations and structural information about these shear zones and associated alkaline dykes, and speculates on their tectonic evolution.

REGIONAL GEOLOGY The PSZ and the IICSZ (Figure 1) cut across several geologic units, such as mafic to intermediate granulites and migmatites of the Archaean-Proterozoic Itabuna Belt, Palaeoproterozoic granitic to anorthositic bodies, Meso- to Neoproterozoic metasedimentary sequences of the Rio Pardo Group, and migmatites and gneisses of the Neoproterozoic Araçuai Fold Belt (Barbosa \& Dominguez 1996). These shear zones are tectonically
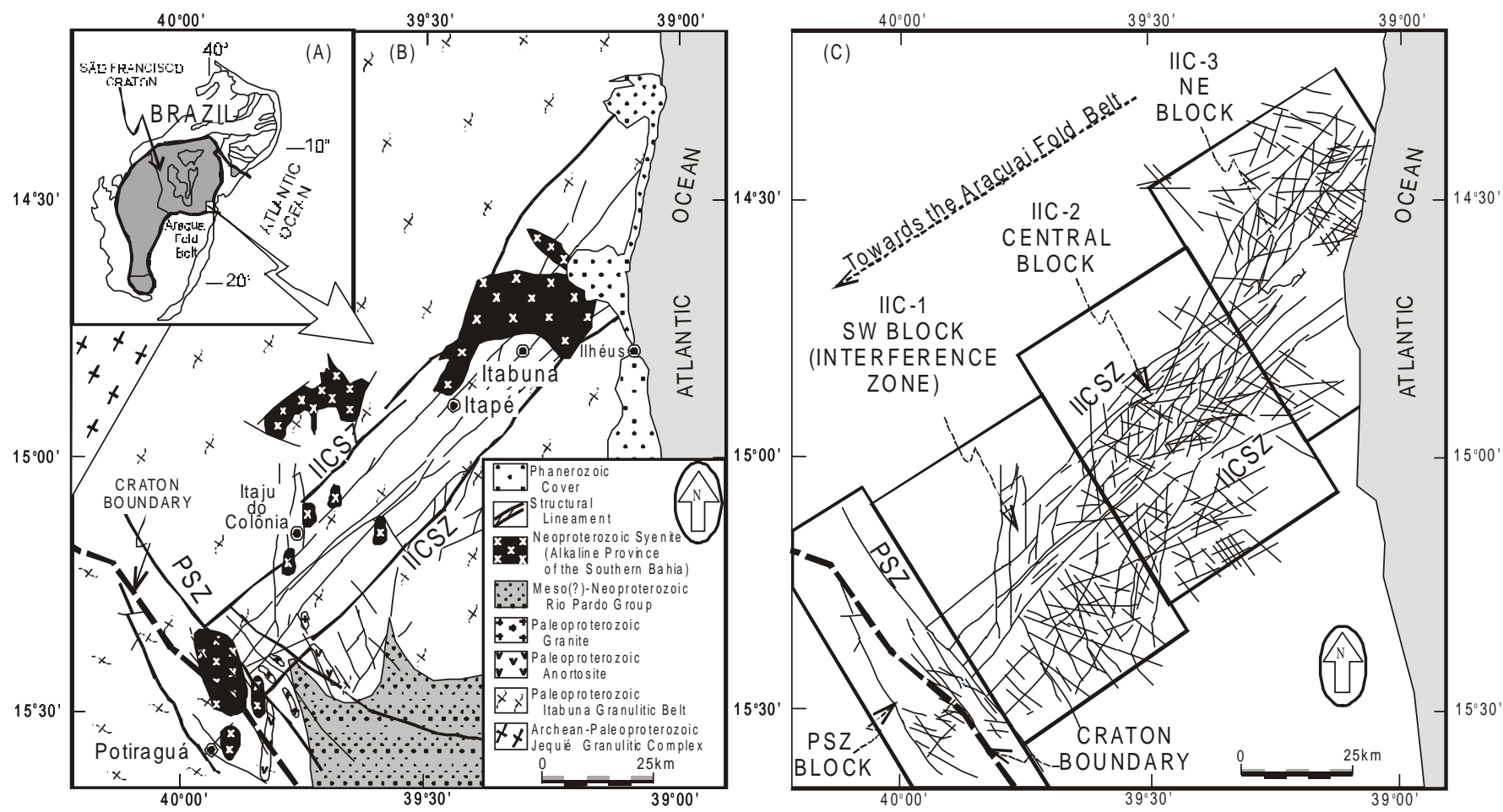

Figure 1 - A. Locality map (note the position of the San Francisco Craton in relation to the Araçuai Fold Belt). B. Regional geology of the study area (modified from Barbosa and Dominguez 1996). C. Main structural blocks and intrinsic lineaments of the Potiraguá (PSZ) and Itabuna-Itaju do Colonia (IICSZ) shear zones.

1 - Centro Federal de Ensino Tecnologico, Rua Emidio Santos, s/n, 40000-Salvador, Brazil

2 - Instituto de Geociências , UNICAMP, PO Box 6152, 13083-970, Campinas, Brazil 
associated with the emplacement of syenites of the Neoproterozoic Alkaline Suite of Southern Bahia (Silva Filho 1978) and with a chrono-correlated mafic to felsic alkaline dyke swarm (Lima et al. 1981, Arcanjo 1993, Corrêa-Gomes et al. 1996, 1998a). According to Cordani et al. (1974), Lima et al. (1981), Teixeira et al. (1997) and Corrêa-Gomes (2000), two main episodes of magma emplacement are recognized: (i) 730-650 Ma - intrusion of syenitic bodies and the first generation of alkaline dykes, and (ii) 550-480 Ma - intrusion of the second generation of alkaline dykes. These age intervals timely constrain the tectonic evolution of the above referred shear zones.

The PSZ trends $\mathrm{N} 140^{\circ}$ and separates the ArchaeanPalaeoproterozoic São Francisco craton (Almeida 1977) from the Neoproterozoic Araçuai Fold Belt (Almeida 1978). It shows evidences of a two-phase deformation. The first, dominantly ductile and related to north-verging thrusts (with a minor dextral strike-slip component), is marked by $\mathrm{N} 90^{\circ} / 30^{\circ} \mathrm{S}$ to $\mathrm{N} 140^{\circ} / 30^{\circ} \mathrm{SW}$ foliations and dip-slip mineral stretching lineations $\left(30^{\circ}\right.$ to $\left.\mathrm{S}-\mathrm{SW}\right)$. The second phase, essentially brittle, is akin to a left-lateral transtension (Corrêa-Gomes et al. 1998b) that produced several fault and fractures trending $\mathrm{N} 140^{\circ}$, $\mathrm{N} 90^{\circ}$ and $\mathrm{N} 45^{\circ}$ with high-angle dips to SW, S and NW, respectively (Figure 1B). Slickensides on fault and fracture planes are generally sub-horizontal (dipping $20^{\circ}$ or less), and are of the strike-slip type. In this paper, the PSZ is regarded as a single structural block (block PSZ, Figure 1C).

The IICSZ is a $45^{\circ}$-trending brittle structure that is restricted to the São Francisco Craton. It cuts across $\mathrm{N} 10^{\circ}-\mathrm{N} 30^{\circ}$-trending high-grade metamorphic rocks with subvertical dips to SE. The IICSZ formed during a sinistral transpressional event (Corrêa-Gomes et al. 1998b) that evolved to a dextral transtension with a minor normal component (Arcanjo 1993, Corrêa-Gomes et al. 1998b). Three distinct sets of structures are associated to these progressive tectonic phases: (i) fault planes and fractures showing high-angle dips $\left(>70^{\circ}\right)$ in $83 \%$ of the studied population; (ii) strike-slip type slickensides plunging less than $30^{\circ}$ to SW; and (iii) high-angle dipping stepovers $\left(>70^{\circ}\right)$. Reactivation features are also common in the IICSZ, such as repolishment of slickensides formed in the first phase by shearing in the second phase.

From SW to NE, the IICSZ can be divided into three blocks based on their distinct structural signature (Figure 1B). Block IIC-1, or zone of interference (or SW block), is the region where the IICSZ and the PSZ cut across each other. NS-, N45 ${ }^{\circ}, \mathrm{N} 110^{\circ}-$ and $\mathrm{N} 140^{\circ}$-trending faults and fractures are dominant in this block. Block IIC-2, or central, is characterized by $\mathrm{N} 45^{\circ}-, \mathrm{N} 70^{\circ}-, \mathrm{N} 90^{\circ}$ - and $\mathrm{N} 110^{\circ}$-trending faults and fractures and by a NE-trending central zone of NS-trending horses. Block IIC-3 hosts $\mathrm{N} 45^{\circ}$-, $\mathrm{N} 90^{\circ}-$, $\mathrm{N} 110^{\circ}$ - and $\mathrm{N} 140^{\circ}$-trending faults and fractures, as well as a large, NE-trending belt of NS-trending horses.

The dynamic evolution of the IICSZ and the PSZ is also marked on the alkaline dykes that intruded them. Most of the kinematic indicators observed in different fault and fracture systems are also portrayed in the dykes, confirming that dyke emplacement and evolution of both the shear zones were concurrent (Figure 2).

3-D STRUCTURE OF THE SHEAR ZONES The 3D-geometry of the brittle structures of the IICSZ and the PSZ (Figure 3) was achieved after a statistical analysis of 6307 measurements of faults and fractures. Poles of planes and dip directions were plotted, respectively, on the lower hemisphere of equal area Lambert-Schmidt stereographic nets, and on Rose diagrams (Fig. 3A). Aspects such as length, frequency, local density, cross-cutting relationships and relative importance were measured and/or observed for all sets of planes that were studied.

This investigation allowed us to demonstrate that the PSZ is indeed asymmetric, trends $\mathrm{N} 140^{\circ}$ and dips steeply to SW (Figures 3B and 3C). The IICSZ shows, from the orogenic belt to the craton, a remarkable interference with the $\mathrm{PSZ} \mathrm{N} 140^{\circ}$-trending planes, a distinct asymmetry, and it dips notably towards NW close to the interference zone. In its central portion, the IICSZ still shows marginal dips towards NW, which are reversed towards SE in the core of the structure. In the north-easternmost part of the IICSZ, the margins are symmetric and dip towards its core (palmtree-like structure), whereas in the center the planes dip to southeast (Figures 3B and 3C).

PALEOSTRESS FIELDS Paleostress fields for the study area we rendered using the inversion methods of Stauder (1962), Pegaroro (1972), Angelier and Mechler (1977) and Lisle (1987, 1988). These methods are based on several mechanical assumptions (Angelier 1994, Dupin et al. 1994), such as: (i) the total coaxial deformation is minimum and rotation is negligible, (ii) slipping of opposite blocks along fault planes is parallel, independent and with the sense of the maximum shearing vector, (iii) rock walls at the fault plane are rigid, and (iv) phase deformation are developed under conditions of homogeneous strain. Consequently, only the kinematic indicators of
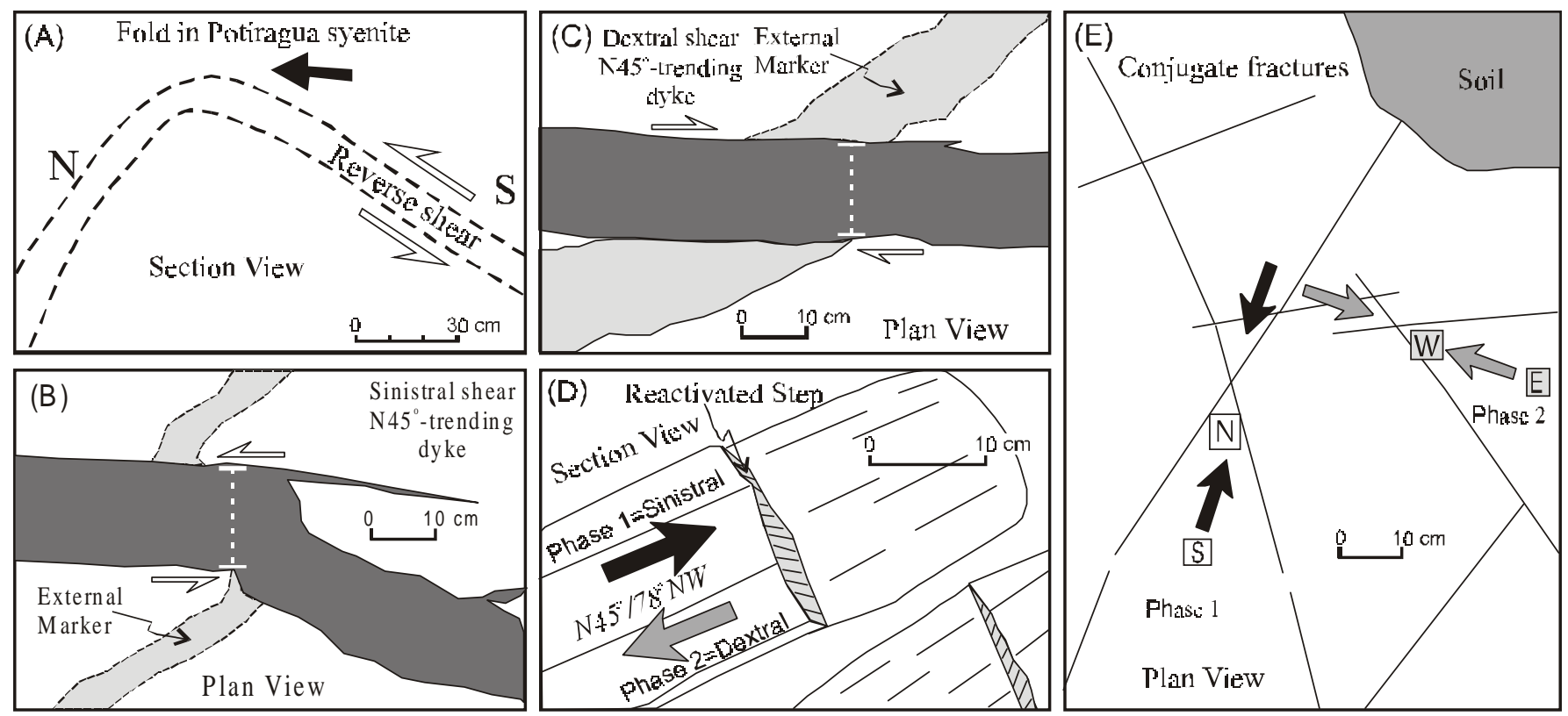

Figure 2 - Kinematic indicators determined along the PSZ and the IICSZ. (A) Asymmetric fold akin to S to N thrusts observed within the Potiragua syenite (black arrow indicates the conventional sense of tectonic transport). Emplacement of alkaline dykes associated with sinistral shearing of the $1^{\text {st }}$ tectonic phase (B) and dextral shearing of the $2^{\text {nd }}$ tectonic phase $(C)$ - white dashed lines indicate the relative motion of external markers. $(D)$ Reactivation of stepovers $\left(N 45^{\circ} / 78^{\circ} N W\right)$ (Itabuna region). (E) Conjugated fractures and orthogonal stress fields, indicating that E-W fractures crosscut $N$-S ones (Potiraguá region, Figure $1 B)$. 

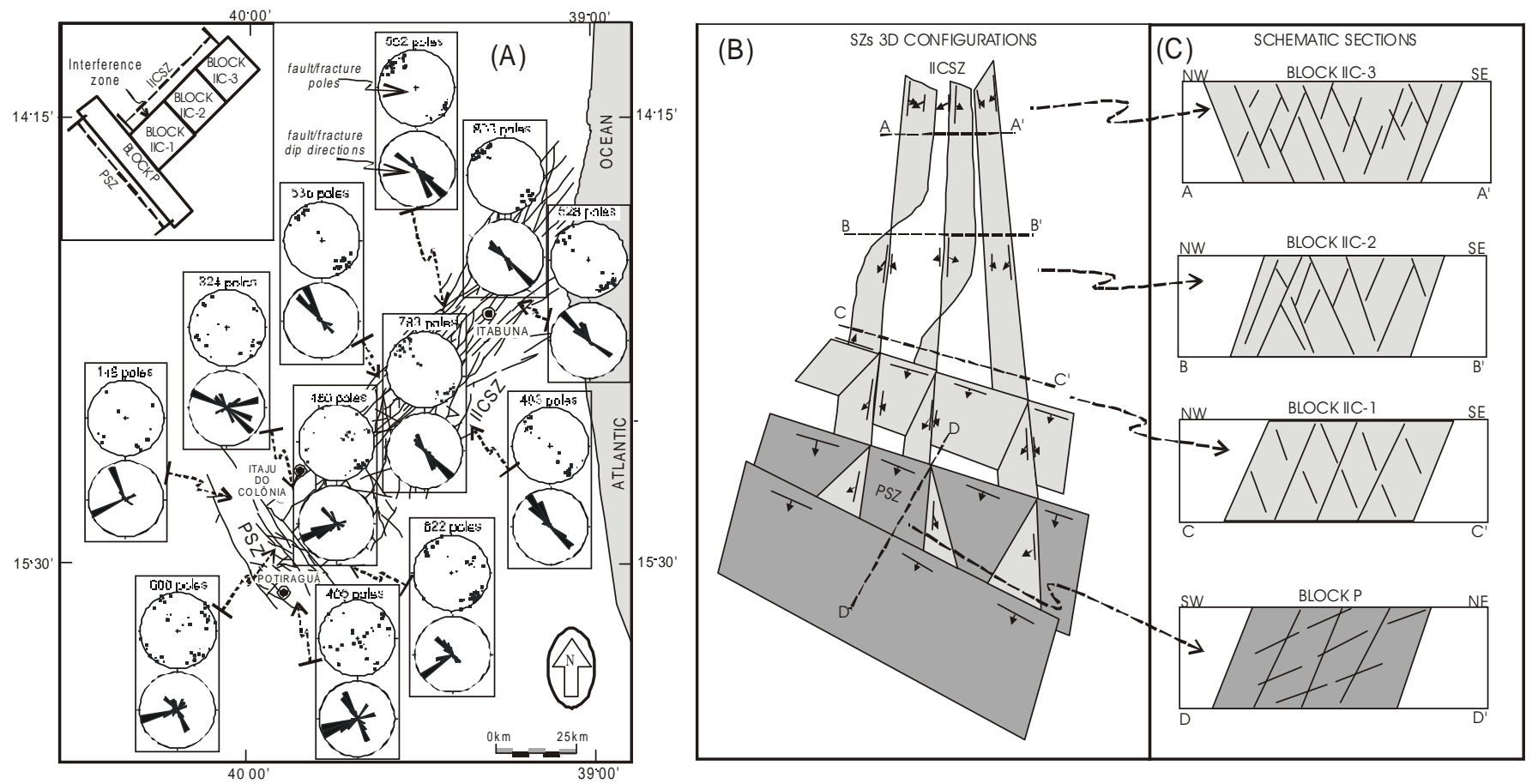

Figure 3 - (A) Main structural blocks of the PSZ and the IICSZ (inset). Fault and fracture planes observed in both shear zones were plotted in Rose diagrams and on the lower hemisphere equal area Lambert-Schmidt stereographic nets (6307 measurements). 3D-geometry (B) and schematic sections of the shear zones $(\boldsymbol{C})$. In the latter, sub-vertical dips of brittle planes were slightly flattened to ease geometric analysis.

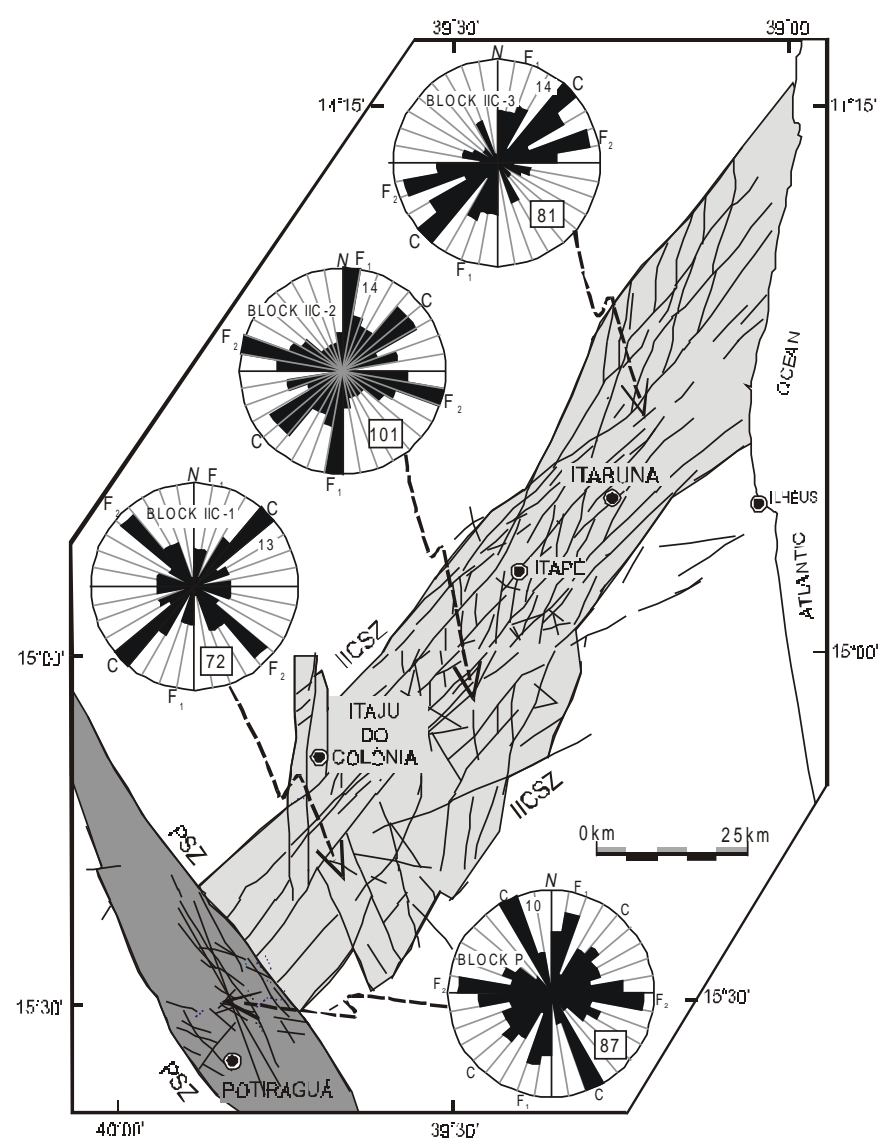

Figure 4 - Rose diagrams of maximum stress tensors $\left(\sigma_{1}\right.$ - horizontal projections) derived for each structural block of the PSZ and the IICSZ (341 measurements). Numbers inside each Rose diagram indicate the total number of measurements by block (boxes) and for dominant directions. $F 1=1^{\text {st }}$ tectonic phase. $F 2=2^{\text {nd }}$ tectonic phase. $C=$ concentration of tension. brittle deformation must be considered, i.e. conjugated and Riedel fractures, gashes and fracture gashes, steps, grooves and slickensides, as well as fracture-filling dykes (with L, Y, X and T shapes) and lateral markers showing a clear off-set.

A total of 341 measurements of local paleostress orientation was taken from different outcrops within the shear zones (Figure 4). The vertical orientation of fracture planes, faults, dykes and their intersections, coupled with horizontal striation and vertical stepping, support the interpretation that the stress tensors $\sigma_{1}$ and $\sigma_{3}$ were horizontal, whereas $\sigma_{2}$ was vertical at the time of fracture formation. In such cases, the orientation of the local paleostress fields may be represented solely by the horizontal component of the maximum paleostress tensor $\left(\sigma_{1}\right)$. This procedure allowed us to plot the stress vector $\left(\sigma_{1}\right)$ on Rose diagrams, and allowed to distinguish the orientation of the paleostress field for different tectonic phases.

DISCUSSION The dynamic evolution of the PSZ and IICSZ is well constrained by the local, maximum paleostress tensor $\left(\sigma_{1}\right)$. For both shear zones, paleostress orientation near $\mathrm{N}^{\circ} 0^{\circ}$ conform with a N$\mathrm{S}$ far field stress that is akin to the first tectonic phase; whereas $\mathrm{N} 90^{\circ}$ paleostress orientation concurs with a E-W far field stress related to the second tectonic phase. $\mathrm{N} 45^{\circ}$ and $\mathrm{N} 140^{\circ}$ paleostress directions are due to tensor concentration ('channeling') throughout the shear zones.

However, the paleostress picture for the second tectonic phase is more complex. The IICSZ, for example, shows orientation of paleostress mainly at $\mathrm{N} 135^{\circ}$ within block IIC-1; N105 ${ }^{\circ}$ within block IIC-2 and $\mathrm{N}^{\circ} 5^{\circ}$ within block IIC-3. Such different orientations seem to indicate disturbances in the direction of the far field stress that affected the IICSZ and the PSZ. In all IICSZ blocks, changes in paleostress fields control the geometry and trends of horses, fault systems and second-order fractures (Figure 1B).

We accept that the orientation of local, maximum paleostress within the studied shear zones can be related to the following: (i) N-S orientation of the far field stress akin to the first tectonic phase; (ii) $\mathrm{N} 45^{\circ}$ and $\mathrm{N} 140^{\circ}$ concentration of stress along the shear zones; and (iii) E-W compressional far field stress of the second tectonic phase, similarly to features observed in reactivated shear zones elsewhere (Homberg et al. 1997). 

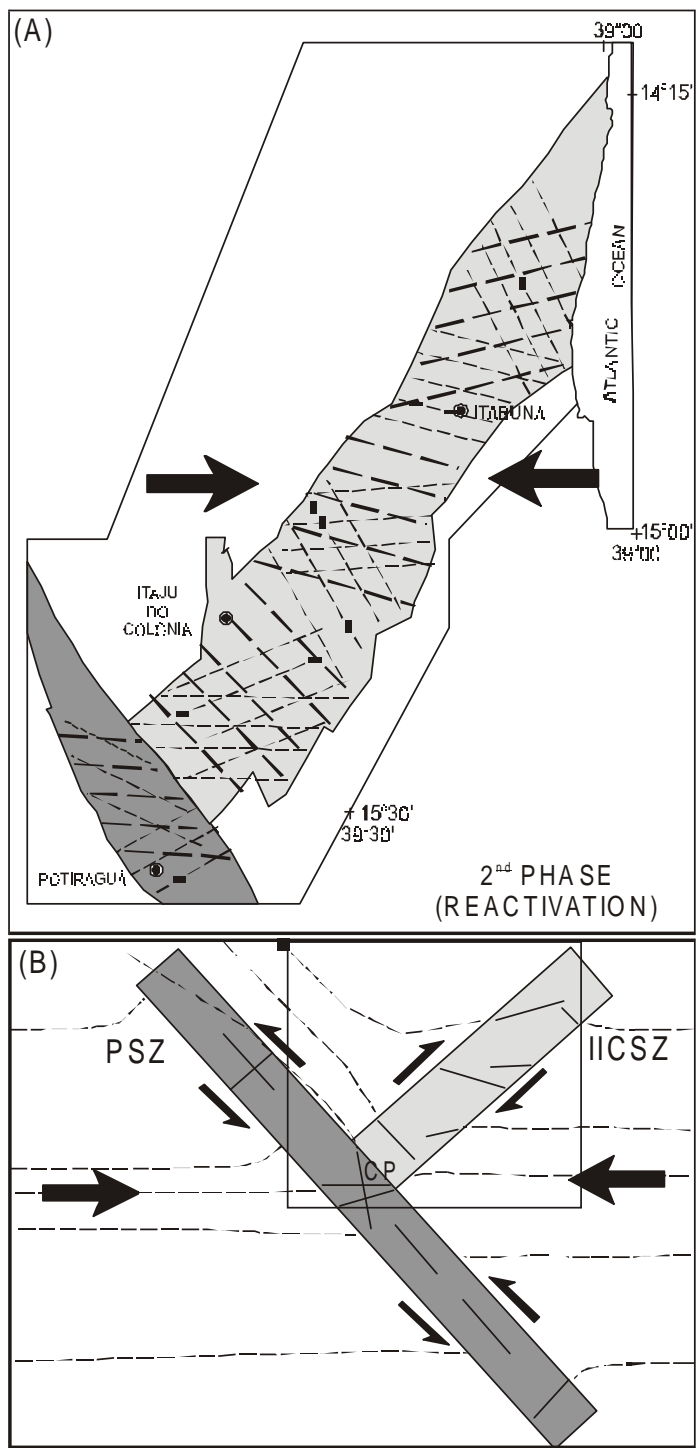

Figure 5 - (A) Orientation of paleostress fields within shear zones of the $2^{\text {nd }}$ tectonic phase. Thick lines indicate dominant directions. (B) Modeling of orientation of stress fields in reactivated shear zones. Note the presence of a point of contact or convergence $(C P)$ between the shear zones (Rawsley et al. 1992, Homberg et al. 1997, Corrêa-Gomes 2000). The box inside Figure 5B outline the study area.
The zone of intersection between the IICSZ and the PSZ presumably also worked as a point of convergence of stress tension, as theoretically predicted by Rawsley et al. (1992), judging from the position of the paleostress fields close to it (Figure 5).

Several other factors may have ruled the orientation of paleostress fields within the PSZ and the IICSZ (Corrêa-Gomes, 2000), at least to some extent. Among these are: (i) the 3D-geometry of the shear zones; (ii) the concentration of stress fields by plane anisotropy either contemporaneous or ancient to the shear zones (faults, fractures and metamorphic foliations); (iii) the transfer of residual stress from one block to another; (iv) the position of the shear zones in relation to the orogen and craton limits due to mechanical differences.

CONCLUSIONS The studied shear zones show distinct 3Dgeometry of the brittle structures. The PSZ is structured in a simple pattern and comprises asymmetric, steep dips to SW. The IICSZ displays a more intricate arrangement - it is asymmetric at the margins and center of the structural block close to the orogen, turning into an approximately symmetric flower structure, further away from the orogen (structural blocks located in the interior of the craton).

Analysis of paleostress fields associated with brittle deformation in both shear zones, allows to achieve the following conclusions: (i) the first tectonic phase was marked by a concentration of the $s_{1}$ component of the far field stress along the N-S direction; (ii) the PSZ and the IICSZ played a major role in the concentration of tension at $\mathrm{N} 140^{\circ} \mathrm{e}$ $\mathrm{N} 45^{\circ}$ trends, respectively; (iii) the second tectonic phase was characterized by a $s_{1}$ component of the far field stress close to the E$\mathrm{W}$ direction, which shows stress trajectory deviations compatible to those described in mechanically reactivated brittle discontinuities elsewhere; (iv) the stress trajectory deviations were responsible for the geometric arrangement of fault and second-order fracture systems documented in different localities of the shear zones; (v) the site of intersection between the shear zones functioned as a point of convergence of stress tension, disturbing the local orientation of the far field stress.

The IICSZ is taken here as a world-class example of field stress trajectory deviations in the vicinities of reactivated faults and probably it is also one of the world's largest $(150 \mathrm{~km}$ by $30 \mathrm{~km})$ structures where such features have been described.

Acknowledgements Field work was supported by FAPESP (Project 96/3582-3). L.C. Corrêa-Gomes was funded by a CAPES research studentship. C.R. de Souza Filho and E.P. Oliveira thank CNPq for their research grants (Nos. 301227/94-2 and 300845/91-0, respectively). To two anonymous referees of RBG for their critical analysis of the manuscript.

\section{References}

Almeida F.F.M. 1977. O Cráton do São Francisco. Rev. Bras. Geociências, 7:349-364. Almeida F.F.M. 1978. A Faixa de Dobramentos Araçuaí na Região do Rio Pardo. In: SBG, Congr. Bras. Geol., 30, Recife, Anais, 1:270-283.

Angelier J. 1994. Fault slip analysis and paleotension reconstruction. In: Hancock. P.L (ed.), Continental Deformation, Pergamon Press, 53-100.

Angelier J., Mechler P. 1977. Sur une méthode graphique de recherche des contraintes princiales également utilisable en tectonique et en séismologie: la methode des dièdres droits. Bulletin de la Societé Géologique de France, 7:1309-1318.

Arcanjo J.B.A. 1993. Folha de Itabuna SD.24.Y.B.VI, Estado da Bahia, escala 1:100.000. DNPM/CPRM, inédito.

Barbosa J.S.F., Dominguez,J. M.L (eds.) 1996. Mapa geológico do estado da Bahia. Texto explicativo. Secretaria da Indústria, Comércio e Mineração e Superintendência de de Geologia e Recursos Minerais, 400p.

Cordani U. G., Bernat M., Teixeira W., Kinoshita H. 1974. Idades radiométricas das rochas alcalinas do sul da Bahia. XXVIII In: SBG, Congr. Bras. Geol., 28, Porto Alegre, Anais, 6:253-259.

Corrêa-Gomes L.C. 2000. Evolução dinâmica da Zona de Cisalhamento neoproterozóica de Itabuna-Itaju do Colônia e do magmatismo fissural alcalino associado (SSE do Estado da Bahia, Brasil). Inst. de Geociências, Universidade Estadual de Campinas, Campinas, Tese de Doutoramento.

Corrêa-Gomes L.C., Tanner de Oliveira M.A.F., Motta A.C., Cruz M.J.M. (eds.) 1996 Províncias dos diques máficos do Estado da Bahia. Mapa, evolução temporal estágio atual do conhecimento. Convênio SICM/SGM/PPPG/UFBA, $144 \mathrm{p}$.

Corrêa-Gomes L.C., Oliveira E.P., Barbosa J.S.F., Tanner de Oliveira M.A.F. 1998a. Circulação magmática em zonas de cisalhamento: os diques alcalinos neoproterozóicos da Zona de Cisalhamento de Itabuna-Itajú do Colônia, SSE do estado da Bahia, Brasil. Rev. Bras. Geociências, 28:509-518.

Corrêa-Gomes L.C., Oliveira E. P., Barbosa J.S.F., Silva P.C.F. 1998b. Tectônica associada à colocação de diques alcalinos félsicos e máficos neoproterozóicos na Zona de Cisalhamento de Itabuna-Itajú do Colônia, Bahia, Brasil. Rev. Bras. Geociências, 28:497-508.
Dupin J-M, Angelier J., Sassi W. 1994. L'hypothèse de jeux de failles indépendamment contrôllés par un état de contraint unique est-elle valable? Une approche numérique 3-D. Bulletin de la Societé Géologique de France, 165:317-328.

Homberg C., Hu, J-C., Angelier J., Lacombe O. 1997. Characterization of stress perturbations near major fault zones: insights from 2-D distinct-element numerical modelling and field studies (Jura mountains). Journal of Structural Geology, 19:703718 .

Lima M.I.C., Fonsêca E.G., Oliveira E.P. et al. 1981. Folha SD-24 Salvador. Cap. 1 Geologia. Projeto RADAMBRASIL, Brasil, Ministério das Minas e Energia, 25-
192 .

Lisle R. J. 1987. Principal stress orientation from faults: an additional constraint. Annales Tectonicae, 1:155-158

Lisle R. J. 1988. ROMSA: a basic program for paleostress analysis using fault striation data Computer and Geosciences, 14:255-259.

Pegaroro O. 1972. Application de la microtectonique à une étude de neotectonique. Le Golfe Maliaque (Grèce centrale). Thesis $3^{\text {eme }}$ cycle; Montpellier, $41 \mathrm{p}$.

Rawnsley K. D., Rives T., Petit J-P., Hencher S. R., Lumsden A. C. 1992. Joint development in perturbed stress fields near faults. Journal of Structural Geology, 14:939-951.

Silva Filho M.A., Mascarenhas J.F., Moraes Filho O., et al. 1974. Projeto Sul da Bahia. Relatório Final.Convênio DNPM/CPRM, Salvador, CPRM, 15 vols

Stauder W. 1962. The focal mechanism of earthquakes. In: Landsberg H.E. and van Mieghem J. (eds.), Advances in Geophysics. Academic Presss, London, 9:1-71

Teixeira, W. Kamo S. L., Arcanjo J.B. A. 1997. U/Pb zircon and baddeleyite age and tectonic interpr.tion of the ItB. A. tectonic interpretation of the Itabuna Alkaline Suite, Sä
Journal of South American Earth Sciences, 10:91-98.

Contribution IGC-174 Received March 8, 2000 Accepted for publication April 30, 2000 